\title{
TNF- $\alpha$ is a mediator of the anti-inflammatory response in a human neonatal model of the non-septic shock syndrome
}

Published online: 16 November 2005

(c) Springer-Verlag 2005

\begin{abstract}
The anti-inflammatory/immunoparalytic phase of the systemic inflammatory response syndrome (SIRS) following major insult (surgery, thermal/traumatic injury) is of major clinical importance in the neonate, during which the risk of infection is particularly great. Here, the mechanisms by which TNF- $\alpha$ production is suppressed in response to infection are largely unknown. We questioned whether TNF- $\alpha$ itself could be a critical mediator of this suppression. Monocytes, isolated from cord blood $(n=3)$, were treated with LPS $(100 \mathrm{ng} / \mathrm{ml})$, TNF- $\alpha$ (10 ng/ml, + / - anti-TNF- $\alpha$ antibody) for 18 and $36 \mathrm{~h}$. Cells were then restimulated with LPS (Gram $-v e)$ or Pam-3-Cys (Gram + ve) for $24 \mathrm{~h}$. This was also done in the presence of selective inhibitors of MAP kinases p38, MEK and JNK. TNF- $\alpha$, IL-6, IL-10 and IL-8 were quantified by ELISA CD86 and HLA-DR expression were determined flow cytometrically. Cells stimulated with LPS for $24 \mathrm{~h}$ produced TNF- $\alpha(282 \mathrm{pg} /$ $\mathrm{ml})$, IL-10 $(1,236 \mathrm{pg} / \mathrm{ml})$, IL-6 $(2,694 \mathrm{pg} / \mathrm{ml})$ and IL-8 $(2,144 \mathrm{pg} / \mathrm{ml})$. In cells pre-exposed to TNF- $\alpha$ for $36 \mathrm{~h}$, there was a significant suppression in TNF- $\alpha$ and IL-6 levels $(9$ and $221 \mathrm{pg} / \mathrm{ml}$, respectively) $(P<0.05)$ with minimal impact on IL-10 $(1,206 \mathrm{pg} / \mathrm{ml})$ and IL-8 levels $(1,886 \mathrm{pg} / \mathrm{ml})$. A similar effect was seen with Pam-3-Cys with a tenfold decrease in levels of TNF- $\alpha$ and IL-6 $(86 \rightarrow 8.5 \mathrm{pg} / \mathrm{ml}$ and $458 \rightarrow 46 \mathrm{pg} / \mathrm{ml}$, respectively) with no effect on IL-10 and IL- 8 levels. Anti-TNF- $\alpha$ antibody negated this effect. Inhibition of p38 kinase reversed the TNF- $\alpha$ effect. Inhibition of the JNK and MEK kinases had no effect. A reduction in the expression of CD86 and HLA-DR was observed. This ex-vivo model of
\end{abstract}

S. Hassett $(\bowtie) \cdot D$. Reen

The Children's Research Centre,

Our Lady's Hospital for Sick Children,

Dublin, Ireland

E-mail: sineadhassett@hotmail.com

Tel.: + 353-1-4096421

Fax: + 353-1-4550201

P. Moynagh

Department of Pharmacology, The Conway Institute, University College Dublin, Dublin, Ireland non-septic SIRS demonstrates that TNF- $\alpha$, released during a major insult, can suppress subsequent monocyte responses to bacterial agents through p38 MAP kinase, making it a potential therapeutic target.

Keywords Neonatal sepsis $\cdot$ Monocyte tolerance $\cdot \mathrm{TNF}-\alpha$

\section{Introduction}

The systemic inflammatory response syndrome (SIRS) occurs where there is inappropriate activation of the immune system [1]. While the initiating events leading to SIRS may be varied, e.g. sepsis, thermal injury, trauma or post major surgery, the subsequent immune pathophysiology following these events is identical [2]. The characteristics of this syndrome are initial massive release of pro-inflammatory cytokines, principally TNF- $\alpha$ and IL1- $\beta$ followed by anergy of the immune system termed "immunoparalysis" and production of the antiinflammatory cytokines IL-10 and TGF- $\beta$ termed the "compensatory anti-inflammatory response" (CARS) [2, $3]$. Recent work in both adult [4, 5] and paediatric populations $[6,7]$ has identified monocyte and macrophage deactivation, which occurs as part of the immunoparalytic phenomenon, as a major predictor for the development of nosocomial infection with restoration of cellular function associated with improvement in the clinical condition of patients $[8,9]$. Improved understanding of the factors causing monocyte/macrophage deactivation has been aided by the realisation that the ex vivo tolerant monocyte possesses the same functional phenotype as its in vivo immunoparalytic counterpart [10-12]. Innate tolerance was originally described with respect to endotoxin and is classically defined as failure of a secondary TNF- $\alpha$ response from a macrophage/ monocyte following initial low dose stimulation $[13,14]$.

There has been no published literature regarding neonatal innate tolerance despite its importance in the development of nosocomial infections, an important 
predictor of mortality in the critically ill neonate [15]. The aim of this study was to assess the ability of neonatal monocytes to undergo tolerance induction. In order to mimic the clinical situation of sepsis, lipopolysaccharide [LPS] and Pam-3- Cys were used. LPS is found in the cell wall of gram-negative bacteria and signals through toll-like receptor (TLR) 4 while Pam-3-Cys is an agonist of TLR2, the surface receptor for gram-positive bacteria [16]. Recreation of the nonseptic situation was performed by exposing neonatal monocytes to TNF- $\alpha$, representing the initial non-septic insult e.g. surgery and then restimulating these monocytes with LPS or Pam-3-Cys representing the bacterial challenge which the critically ill post-operative neonate commonly encounters in the intensive care environment.

\section{Material and methods}

\section{Materials}

IMDM and HBSS were purchased from BioWhitaker (Wokingham, UK). Human recombinant TNF- $\alpha$ and anti-human TNF- $\alpha$ antibody were purchased from R and D systems (Oxon, UK). LPS (Escherichia coli serotype 055:B5) was obtained from Sigma-Aldrich (Dublin, Ireland). Pam-3- Cys ( $N$-Palmitoyl-S-(17)-(18)cysteinyl-(18)-seryl-(18)-lysl-(18)-lysl-(18)-lysl-(18)-ly-

sine $\times 3 \mathrm{HCL}$ ) was obtained from EMC microcollections (Tuebingen, Germany). Anti-human CD14(PE) CD45 (FITC) mouse anti-human CD45(clone MOPC21) $\operatorname{IgG} 1$, mouse anti-human (clone $2 \mathrm{D} 1 \mathrm{M} \phi \mathrm{P}$ ) $\operatorname{IgG} 2 \mathrm{a}$ human anti-TNF(APC) and mouse anti-human (clone Mab11)IgG1 were purchased from BD Biosciences (Oxford, UK). SB203580, PD98059, SP600125, SB202474 and JNK inhibitor negative control, $N$-methyl-1,9-pyrazoloanthrone were purchased from Calbiochem (Nottingham, UK).

Every effort was made to ensure minimal contamination with LPS in our system. All steps in monocyte purification protocols and culturing were conducted using certified non-pyrogenic plastics (Corning/Costar, Bucks, UK) and media certified to have an endotoxin level of 0.005 endotoxin $\mathrm{U} / \mathrm{ml}$ (BioWhittaker). All solutions were made up with endotoxin-free water (Nanopure, Barnstead, UK)

\section{Monocyte isolation}

Cord blood was obtained with full consent following full-term normal deliveries. This was then diluted $1 / 1$ with HBSS. PBMCs were separated by density centrifugation through Ficoll-Hypaque (Lymphoprep, Nycomed, Oslo, Sweden), washed twice in cold HBSS and resuspended in IMDM $(1 \mathrm{ml})$ and PBMC count determined by ethidium bromide and acridine orange staining. Monocytes were isolated from PBMCs by negative selection according to the manufacturer's protocol
(Miltenyi Biotec, Surrey, UK). Monocyte purity, determined flow cytometrically using two-colour flow cytometric analysis (CD14/CD45), was $>80 \%$.

\section{Analysis of cytokines}

Cytokine concentrations in the cellular supernatants were determined by ELISA using TNF- $\alpha$-matched $\mathrm{Ab}$ pairs (R\&D Systems) and OptEIA human IL-10, IL6 and IL-8 sets (BD Pharmingen, Oxford, UK). Assays were performed according to the instructions provided. Colour development was assessed using a VERSA-max microplate reader (Biosciences, Dublin, Ireland). Intracellular cytokine estimation was performed as described previously [19]. Cells were stained with surface markers CD14FITC, CD45PerCp, HLA-DRPE, CD86FITC and CD80 Cy-chrome (BD, Pharmingen) at room temperature for $10 \mathrm{~min}$. Cells were washed with ice-cold PBS and following this were fixed with Cytofix (Pharmingen, San Diego, USA) for $20 \mathrm{~min}$ at $4^{\circ} \mathrm{C}$. Cells were then permeabilised with ice-cold permwash (Pharmingen, San Diego, USA), washed and resuspended in $100 \mu \mathrm{l}$ of PBA. The intracellular antibody TNF- $\alpha$ APC was then added for $30 \mathrm{~min}$ at room temperature. The cells were then washed in ice-cold permwash, resuspended in $200 \mu \mathrm{l}$ of PBA and assessed by flow cytometry.

\section{Statistical analysis}

The Mann-Whitney non-parametric test was performed using the software SPSS for Windows.

\section{Results}

We first examined the primary cytokine output from the proposed tolerising agents. Figure 1a demonstrates the cytokine output from neonatal monocytes stimulated with LPS. There is significantly less $(P<0.005) \mathrm{TNF}-\alpha$ and IL-10 production from neonatal monocytes in comparison to their adult counterparts. Interestingly, there are comparable levels of IL- $1 \beta$, IL- 6 and IL-8 production. Pam-3-Cys is not as potent a stimulus as LPS and this is reflected in Fig. $1 \mathrm{~b}$ where there is a global reduction in measured cytokine levels. Neonatal monocytes produce significantly less $(P<0.01) \mathrm{TNF}-\alpha$ and IL-10 in relation to their adult counterparts in common with Fig. 1a. Similarly IL1- $\beta$, IL-6 and IL-8 levels are comparable with adult monocytes. TNF- $\alpha$ stimulation of neonatal and adult monocytes is shown in Fig. 1c. There is a significant reduction $(P<0.05)$ in the amount of IL-10 produced from neonatal monocytes with no significant attenuation noted in relation to IL-6 and IL-8. There were no measurable levels of IL-1 $\beta$ produced from either neonatal or adult monocytes. TNF- $\alpha$ could not be measured by ELISA due to the presence of exogenous TNF- $\alpha$ in the cellular 
Fig. 1 A quantity of $0.5 \times 10^{6} / \mathrm{ml}$ of neonatal and adult monocytes were cultured in IMDM $/ 10 \%$ autologous serum and stimulated with a LPS $(1 \mu \mathrm{g} / \mathrm{ml})$, b Pam-3 Cys $(1 \mu \mathrm{g} /$ $\mathrm{ml})$ or $\mathbf{c}$ human recombinant TNF $-\alpha(1 \mu \mathrm{g} / \mathrm{ml})$ for a period of $24 \mathrm{~h}$. Following this time point the cellular supernatant was collected and stored at $-70^{\circ} \mathrm{C}$ until analysed by ELISA $(n=6)$. Data representative of mean $\pm \mathrm{SD}$
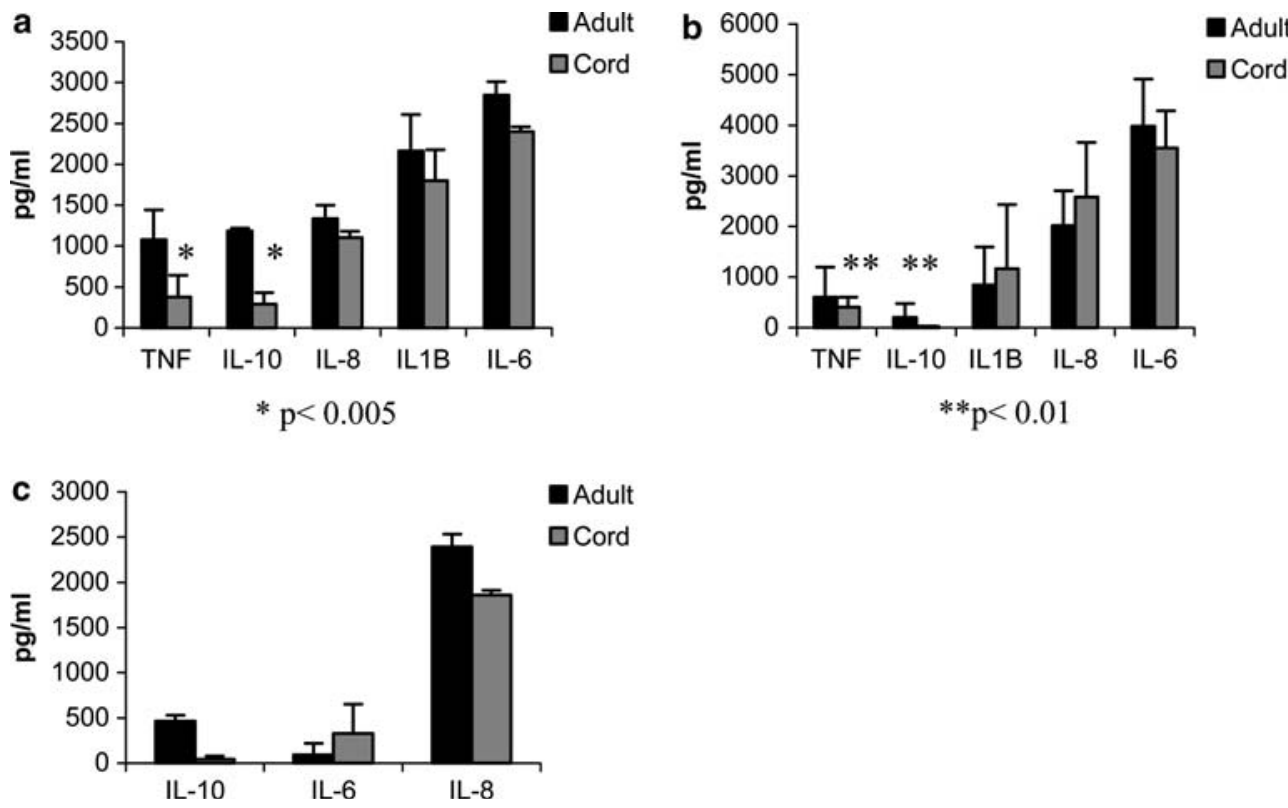

supernatant. Neonatal monocytes are capable of undergoing tolerance to LPS and Pam-3-Cys with the same time kinetic as adult monocytes (Fig. 2a). Innate tolerance is defined as a lack of $\mathrm{TNF}-\alpha$ production on secondary stimulation. Neonatal monocytes treated with either LPS or Pam-3-Cys and then restimulated $18 \mathrm{hr}$ later with higher doses of the same stimulus for a further $24 \mathrm{~h}$ failed to produce $\mathrm{TNF}-\alpha$ in comparison to those cells which did not receive the initial low dose stimulation. We next looked at TNF- $\alpha$ as an inducer of tolerance. The current dogma is that TNF- $\alpha$ is not capable of tolerance induction $[20,21]$. This is shown in Fig. 3a where at $18 \mathrm{~h}$ there is still a substantial secondary TNF$\alpha$ response following secondary LPS or Pam-3-Cys stimulation. Interestingly, when the $\mathrm{TNF}-\alpha$ pre-treatment time kinetic is extended to $36 \mathrm{~h}, \mathrm{TNF}-\alpha$ causes tolerance as judged by lack of $\mathrm{TNF}-\alpha$ production on secondary stimulation with LPS and Pam-3-Cys. Substantial amounts of IL-10 and IL- 8 are produced from these $\mathrm{TNF}-\alpha$ tolerant cells with a significant reduction in

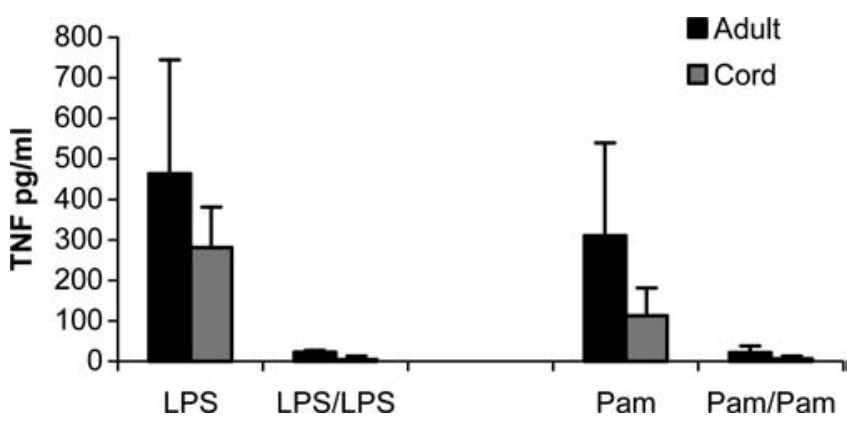

Fig. 2 A quantity of $0.5 \times 10^{6} / \mathrm{ml}$ neonatal and adult monocytes were cultured for $18 \mathrm{~h}$ with LPS $(100 \mathrm{ng} / \mathrm{ml})$ or Pam-3-Cys $(100 \mathrm{ng} / \mathrm{ml})$ for $18 \mathrm{~h}$. The cells were then washed twice and restimulated with LPS $(1 \mu \mathrm{g} / \mathrm{ml})$ or Pam-3-Cys $(1 \mu \mathrm{g} / \mathrm{ml})$ for a further $24 \mathrm{~h}$. The cellular supernatant was collected and stored at $-70^{\circ} \mathrm{C}$ until analysed. TNF- $\alpha$ was measured by ELISA $(n=5)$. Data representative of mean $\pm \mathrm{SD}$
IL-6 secretion $(P<0.05)$, in keeping with the idea that tolerant cells exhibit a reorientation of their functional phenotype as opposed to a global reduction in the cytokine producing capacity of the monocyte.

Further evidence that $\mathrm{TNF}-\alpha$ is acting as a tolerising agent is provided by analysis of the surface antigens CD86 and HLA-DR. Downregulation of both HLADR and CD86 is present in the TNF- $\alpha$ tolerant cell in common with published results on LPS tolerance induction [22] (Fig. 4a, b).

Neutralisation of TNF- $\alpha$ was performed using antiTNF- $\alpha$ antibody to ensure that the results obtained were due exclusively to TNF- $\alpha$. In the presence of anti-TNF$\alpha$, tolerance does not occur as evidenced by a substantial TNF $-\alpha$ response following secondary LPS stimulation (Fig. 5a). To elucidate the mechanisms of TNF- $\alpha$ tolerance induction, specific inhibitors of the MAP kinase pathway were employed. The MAP kinase pathway is one of the chief pathways activated by TNF- $\alpha[23,24]$. The MAP kinase proteins ERK, JNK and p38 are phosphorylated leading to activation of downstream mediators resulting in gene transcription and ultimately cytokine production [25].

The inhibitors SP600125, PD98059 and SB 203580 prevent phosphorylation of JNK, ERK and p38, respectively [26-28]. While inhibition of ERK and JNK does not prevent TNF- $\alpha$ from inducing tolerance, inactivation of p38 by SB 203580 does, as evidenced by a substantial $\mathrm{TNF}-\alpha$ response upon secondary LPS stimulation (Fig. 5b).

\section{Discussion}

There has been much discussion in the literature over the last decade regarding the role of the monocyte in the neonatal immune response. The rapidity of clinical deterioration in septic neonates suggests an inefficiency 
Fig. 3 A quantity of $0.5 \times 10^{6} / \mathrm{ml}$ neonatal monocytes were stimulated with TNF- $\alpha(10 \mathrm{ng} /$ $\mathrm{ml}$ ) for 18 and $36 \mathrm{~h}$. These cells were then washed extensively and restimulated with LPS $(1 \mu \mathrm{g} / \mathrm{ml})$ or Pam-3-Cys $(1 \mu \mathrm{g} /$ $\mathrm{ml}$ ) for a further $24 \mathrm{~h}$.

Following this time period cellular supernatant was collected and stored at $-70^{\circ} \mathrm{C}$ until further analysis. TNF- $\alpha$, I L-10,IL-6 and IL-8 were measured by ELISA $(n=3)$. Data representative of mean \pm SD

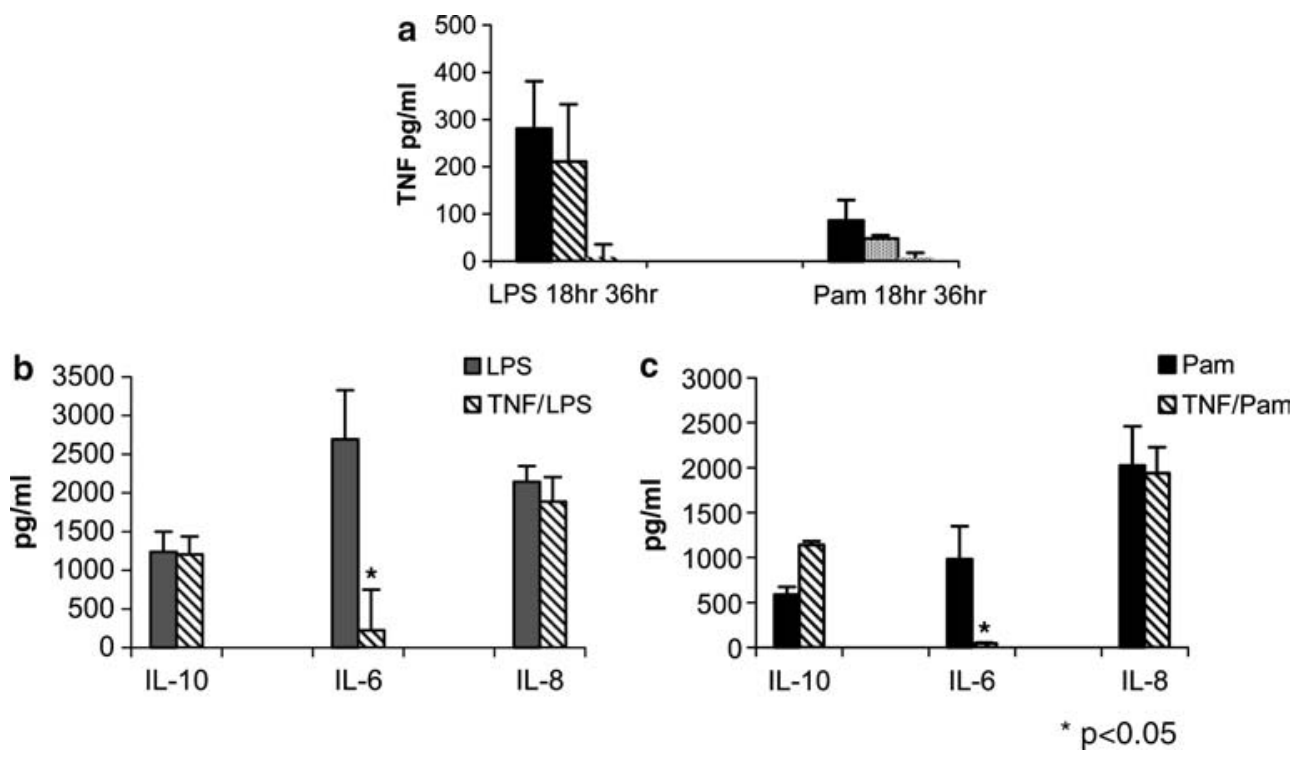

of the innate immune system to mount an effective response allowing rapid progression to multiple organ dysfunction [29]. The data presented here agrees with the published literature demonstrating that neonatal monocytes produce equivalent levels of IL-6, IL-8 and IL1- $\beta$, with TNF- $\alpha$ the only element of the pro-inflammatory response to exhibit reduced levels following LPS and Pam-3-Cys stimulation [30-33]. The results also show that IL-10 production is significantly reduced in relation to adult monocytes following stimulation with LPS, Pam-3-Cys and TNF- $\alpha$. Signal transduction of LPS and Pam-3-Cys occurs via the surface receptors TLR4 and TLR 2, respectively [17, 34]. Activation of these surface receptors ultimately leads to gene transcription of both pro- and anti-inflammatory cytokines [35]. The finding that neonatal monocytes produce comparable levels of the pro-inflammatory cytokines IL-6, IL-8 and IL-1 $\beta$ suggests, in agreement with published studies [30], that similar amounts of TLR receptors are present on the cell surface of neonatal monocytes and that the discrepancies seen in relation to $\mathrm{TNF}-\alpha$ and IL-10 production as illustrated here are due to distinct inherent deficiencies present in the neonatal monocyte in relation to the pathways involved specifically in TNF- $\alpha$ and IL-10 production. This data coupled

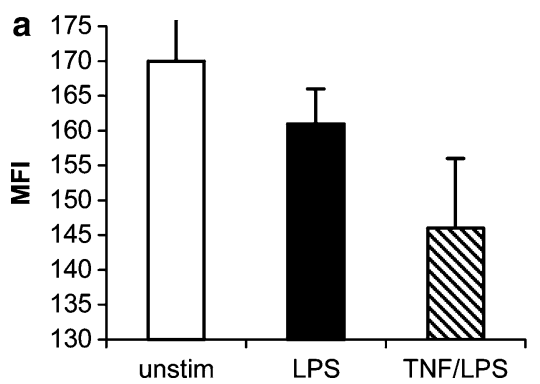

Fig. 4 A quantity of $0.5 \times 10^{6} / \mathrm{ml}$ neonatal monocytes were stimulated with TNF- $\alpha(10 \mathrm{ng} / \mathrm{ml})$ for $36 \mathrm{~h}$. Cells were then washed twice and restimulated with LPS $(1 \mu \mathrm{g} / \mathrm{ml})$ for a further $24 \mathrm{~h}$. Cells were harvested and stained for $30 \mathrm{~min}$ with a CD86 and b HLA-DR. with published work on the other main anti-inflammatory cytokine TGF- $\beta$ illustrate clearly that both components of the neonatal anti-inflammatory response are deficient [36]. One could argue that a factor leading to rapid deterioration of the septic neonate is inefficient counterbalancing of the anti-inflammatory component of the inflammatory response resulting in a predominance of the pro-inflammatory element of the neonatal innate immune response occurring as a result of inherent deficiencies within the neonatal cell as opposed to the virulence of the infecting organism as is the case in adults.

Inappropriate monocyte activation is central to the initiation and progression of SIRS. Activation of monocytes following any major insult results in massive and inappropriate release of the pro-inflammatory cytokines TNF- $\alpha$, IL1- $\beta$, IL-6 and IL-8 [37]. In large quantities these cytokines cause a reduction in vascular tone and myocardial contractility resulting in hypotension [38]. They also stimulate release of tissue factor, a potent activator of coagulation, from endothelial cells and cause a reduction in expression of thrombomodulin, an inhibitor of coagulation, resulting in intravascular thrombosis [39].

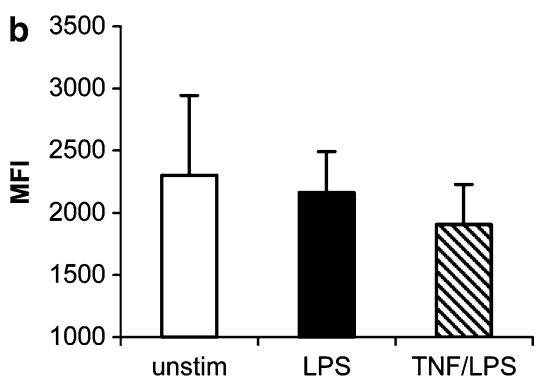

Following this time period, cells were assessed for surface expression of both molecules by flow cytometry $(n=3)$. Data representative of mean $\pm \mathrm{SD}$ 

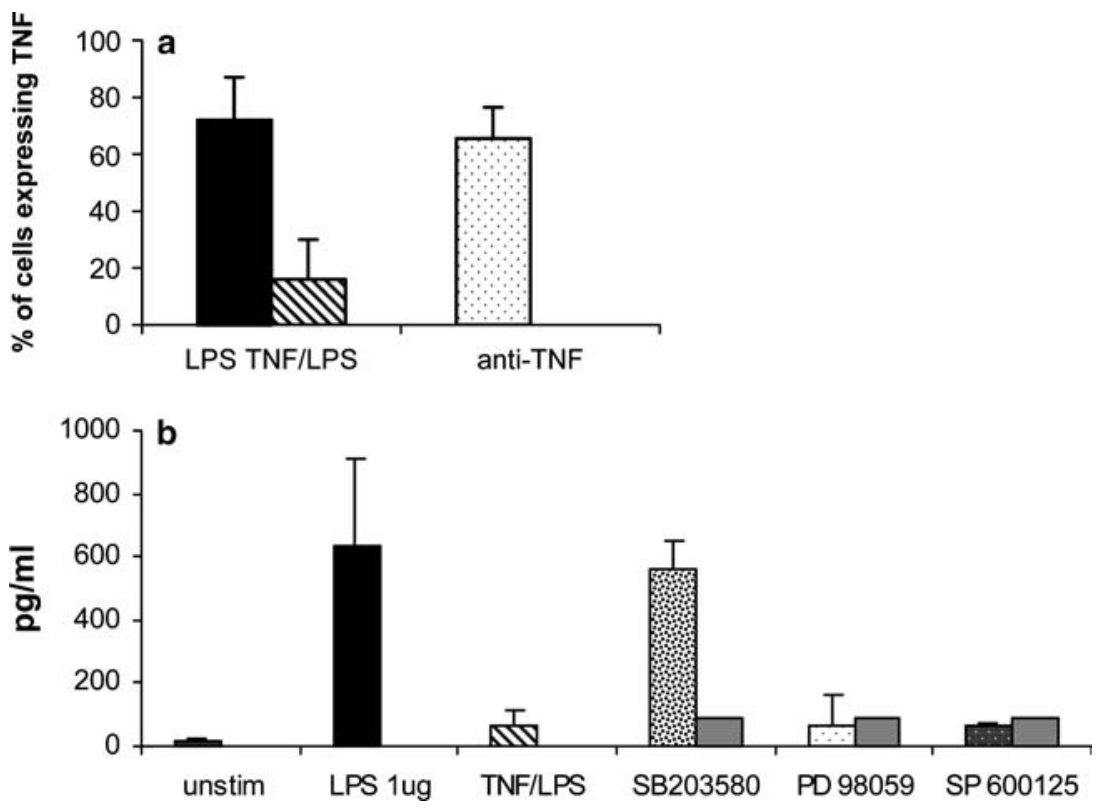

Fig. 5 a A quantity of $0.5 \times 10^{6} / \mathrm{ml}$ neonatal monocytes were stimulated for $36 \mathrm{~h}$ with $\mathrm{TNF}-\alpha(10 \mathrm{ng} / \mathrm{ml})$ in the presence or absence of anti-TNF- $\alpha$ neutralising antibody. Following this time period, cells were washed and restimulated with LPS $(1 \mu \mathrm{g} / \mathrm{ml})$ for a further $4 \mathrm{~h}$. Cells were harvested and stained with TNF- $\alpha$ for 30 min. Estimation of intracellular levels of TNF- $\alpha$ was performed by flow cytometry $(n=3)$. Data representative of mean \pm SD. b Monocytes were stimulated for $36 \mathrm{~h}$ with TNF- $\alpha(10 \mathrm{ng} / \mathrm{ml})$ in the

The net effect of these events is hypoxia of tissues and organs, causing ischemic injury, further activating the immune response and a viscous cycle ensues [40, 41]. From an immunological standpoint, the mechanisms governing the inflammatory response are disrupted due to the inappropriate pro-inflammatory response and a prolonged period of immunoparalysis and predominance of anti-inflammatory cytokine production ensues. This period in SIRS has also been referred to as "CARS" [2, 36].

Monocytes from patients in CARS are identified as failing to mount a secondary TNF- $\alpha$ response following stimulation and also exhibit a downregulation of the surface receptors CD86 and HLA-DR [42-44]. These receptors are important in presentation of the foreign antigen to the $\mathrm{T}$ cells of the adaptative immune system and so activation of the adaptative immune system is hindered while this downregulation is present [45]. Not surprisingly, patients are more susceptible to invading organisms during this period causing further monocyte activation and a viscous cycle is created leading to multiple organ dysfunction syndrome (MODS) with its associated high mortality rates.

The monocyte phenotype from patients in CARS is identical to the ex-vivo tolerant monocyte [10-12] allowing ex vivo investigation into the many mediators involved in the creation of the immunoparalysis witnessed in the CARS phase of SIRS. presence or absence of the MAP kinase inhibitors SB203580 $(10 \mu \mathrm{M} / \mathrm{ml})$, PD $98059(10 \mu \mathrm{M} / \mathrm{ml})$ and SP600125 $(10 \mu \mathrm{M} / \mathrm{ml})$ Following this time period, the cells were washed extensively and restimulated with LPS $(1 \mu \mathrm{g} / \mathrm{ml})$ for a further $24 \mathrm{~h}$. The cellular supernatant was harvested and stored at $-70^{\circ} \mathrm{C}$ until cytokine estimation was performed using ELISA $(n=3)$. Data representative of mean $\pm \mathrm{SD}$

The results from our study illustrate that neonatal monocytes are capable of tolerance induction by LPS and Pam-3-Cys in a manner identical to their adult counterparts. This implies that similar kinetics of immunoparalysis exist in the septic Gram-positive and Gram-negative neonate making therapeutic interventions, e.g. the use of interferon gamma to reverse immunoparalysis, already successfully tried in the adult population, a distinct possibility in the neonatal population $[8,9]$.

The immune pathophysiology which occurs in the non-septic SIRS situation is identical to that in the septic SIRS situation. While it is agreed that endotoxin is the main cause of immunoparalysis in septic SIRS, the causal agents in the non-septic situation have been harder to define. Reductionist ex vivo investigation into the mechanisms of tolerance has identified possible roles for IL1- $\beta$, prostaglandins, corticosteroids and IL-10 [21, $46-48]$.

Interestingly, despite early in vivo adult work demonstrating evidence of TNF- $\alpha$ tolerance induction using end points of survival and weight loss [49-51], more recent ex vivo studies have failed to demonstrate any role for this cytokine in tolerance induction [20, 52, 53].

The data presented here shows that in the neonatal monocyte population TNF- $\alpha$ is capable of inducing tolerance by extension of the tolerising time kinetic. The $36 \mathrm{~h}$ kinetic was chosen in an attempt to mirror the 
longer time point present in the in-vivo work. This finding is strengthened by our results which also show a downregulation of CD86 and HLA-DR in keeping with the tolerant phenotype described in the literature. Tolerance is achieved by TNF- $\alpha$ through activation of the p38 pathway. Interestingly, other investigators have also shown this result in relation to LPS tolerance induction in adult cells [54]. This novel finding provides evidence for the first time that TNF- $\alpha$, the archetypal proinflammatory cytokine, displays anti-inflammatory properties by virtue of its involvement in the creation of immunoparalysis in the non-septic SIRS situation. The identification of p38 as the critical molecule involved helps to provide a framework for the development of a potential therapeutic target in the management of nonseptic SIRS patients in the future.

\section{References}

1. Bone RC (1996) Toward a theory regarding the pathogenesis of the systemic inflammatory response syndrome: what we do and do not know about cytokine regulation. Crit Care Med 24:163172

2. Oberholzer A, Oberholzer C, Moldawer LL (2001) Sepsis syndromes: understanding the role of innate and acquired immunity. Shock 16:83-96

3. Munford RS Pugin J (2001) Normal responses to injury prevent systemic inflammation and can be immunosuppressive. Am J Respir Crit Care Med 163:316-321

4. Asadullah K, Woiciechowsky C, Docke WD, Egerer K, Kox WJ, Vogel S, Sterry W, Volk HD (1995) Very low monocytic HLA-DR expression indicates high risk of infection-immunomonitoring for patients after neurosurgery and patients during high dose steroid therapy. Eur J Emerg Med 2:184-190

5. Muehlstedt SG, Lyte M, Rodriguez JL (2002) Increased IL-10 production and HLA-DR suppression in the lungs of injured patients precede the development of nosocomial pneumonia. Shock 17:443-450

6. Peters M, Petros A, Dixon G, Inwald D, Klein N (1999) Acquired immunoparalysis in paediatric intensive care: prospective observational study. BMJ 319:609-610

7. Allen ML, Peters MJ, Goldman A, Elliott M, James I, Callard R, Klein NJ (2002) Early postoperative monocyte deactivation predicts systemic inflammation and prolonged stay in pediatric cardiac intensive care. Crit Care Med 30:1140-1145

8. Kox WJ, Bone RC, Krausch D, Docke WD, Kox SN, Wauer H, Egerer K, Querner S, Asadullah K, von Baehr R, Volk HD (1997) Interferon gamma-1b in the treatment of compensatory anti-inflammatory response syndrome. A new approach: proof of principle. Arch Intern Med 157:389-393

9. Docke WD, Randow F, Syrbe U, Krausch D, Asadullah K, Reinke P, Volk HD, Kox W (1997) Monocyte deactivation in septic patients: restoration by IFN-gamma treatment. Nat Med 3:678-681

10. Munoz C, Carlet J, Fitting C, Misset B, Bleriot JP, Cavaillon JM (1991) Dysregulation of in vitro cytokine production by monocytes during sepsis. J Clin Invest 88:1747-1754

11. Flach R, Majetschak M, Heukamp T, Jennissen V, Flohe S, Borgermann J, Obertacke U, Schade FU (1999) Relation of ex vivo stimulated blood cytokine synthesis to post-traumatic sepsis. Cytokine 11:173-178

12. Shahbazian LM, Jeevanandam M, Petersen SR (1999) Release of proinflammatory cytokines by mitogen-stimulated peripheral blood mononuclear cells from critically ill multiple-trauma victims. Metabolism 48:1397-1401

13. Brooke MS (1965) Conversion of immunological paralysis to immunity by endotoxin. Nature 206:635-636
14. Milner KC (1973) Patterns of tolerance to endotoxin. J Infect Dis 128:Suppl:237-245

15. Brady MT (2005) Health care-associated infections in the neonatal intensive care unit. Am J Infect Control 33:268-275

16. Dobrovolskaia MA, Medvedev AE, Thomas KE, Cuesta N, Toshchakov V, Ren T, Cody MJ, Michalek SM, Rice NR, Vogel SN (2003) Induction of in vitro reprogramming by Tolllike receptor (TLR)2 and TLR4 agonists in murine macrophages: effects of TLR "homotolerance" versus "heterotolerance" on NF-kappa B signaling pathway components. J Immunol 170:508-519

17. Siedlar M, Frankenberger M, Benkhart E, Espevik T, Quirling M, Brand K, Zembala M, Ziegler-Heitbrock L (2004) Tolerance induced by the lipopeptide Pam3Cys is due to ablation of IL-1R-associated kinase-1. J Immunol 173:2736-2745

18. Abbas A, Lichtman A, Pober J (2000) Cells and tissues of the Immune system. In: Cellular and molecular immunology, 4th edn. WB Saunders, Philadelphia., pp 17-22

19. Prussin C, Metcalfe DD (1995) Detection of intracytoplasmic cytokine using flow cytometry and directly conjugated anticytokine antibodies. J Immunol Methods 188:117-128

20. Li MH, Seatter SC, Manthei R, Bubrick M, West MA (1994) Macrophage endotoxin tolerance: effect of TNF or endotoxin pretreatment. J Surg Res 57:85-92

21. Medvedev AE, Kopydlowski KM, Vogel SN (2000) Inhibition of lipopolysaccharide-induced signal transduction in endotoxin-tolerized mouse macrophages: dysregulation of cytokine, chemokine, and toll-like receptor 2 and 4 gene expression. J Immunol 164:5564-5574

22. Wolk K, Docke WD, von Baehr V, Volk HD, Sabat R (2000) Impaired antigen presentation by human monocytes during endotoxin tolerance. Blood 96:218-223

23. MacEwan DJ (2002) TNF receptor subtype signalling: differences and cellular consequences. Cell Signal 14:477-492

24. Aggarwal BB (2003) Signalling pathways of the TNF superfamily: a double-edged sword. Nat Rev Immunol 3:745-756

25. Wajant H, Henkler F, Scheurich P (2001) The TNF-receptorassociated factor family: scaffold molecules for cytokine receptors, kinases and their regulators. Cell Signal 13:389400

26. Han Z, Boyle DL, Chang L, Bennett B, Karin M, Yang L, Manning AM, Firestein GS (2001) c-Jun N-terminal kinase is required for metalloproteinase expression and joint destruction in inflammatory arthritis. J Clin Invest 108:73-81

27. Langlois WJ, Sasaoka T, Saltiel AR, Olefsky JM (1995) Negative feedback regulation and desensitization of insulin- and epidermal growth factor-stimulated p21ras activation. J Biol Chem 270:25320-25323

28. Garcia J, Lemercier B, Roman-Roman S, Rawadi G (1998) A Mycoplasma fermentans-derived synthetic lipopeptide induces AP-1 and NF-kappaB activity and cytokine secretion in macrophages via the activation of mitogen-activated protein kinase pathways. J Biol Chem 273:34391-34398

29. Stoll BJ, Holman RC, Schuchat A (1998) Decline in sepsisassociated neonatal and infant deaths in the United States, 1979 through 1994. Pediatrics 102:e18

30. Levy O, Zarember KA, Roy RM, Cywes C, Godowski PJ, Wessels MR (2004) Selective impairment of TLR-mediated innate immunity in human newborns: neonatal blood plasma reduces monocyte TNF-alpha induction by bacterial lipopeptides, lipopolysaccharide, and imiquimod, but preserves the response to R-848. J Immunol 173:4627-4634

31. Kotiranta-Ainamo A, Rautonen J, Rautonen N (1997) Interleukin-10 production by cord blood mononuclear cells. Pediatr Res 41:110-113

32. Berner R, Welter P, Brandis M (2002) Cytokine expression of cord and adult blood mononuclear cells in response to Streptococcus agalactiae. Pediatr Res 51:304-309

33. Bessler H, Komlos L, Punsky I, Ntambi JA, Bergman M, Straussberg R, Sirota L (2001) CD14 receptor expression and lipopolysaccharide-induced cytokine production in preterm and term neonates. Biol Neonate 80:186-192 
34. Chow JC, Young DW, Golenbock DT, Christ WJ, Gusovsky F (1999) Toll-like receptor-4 mediates lipopolysaccharide-induced signal transduction. J Biol Chem 274:10689-10692

35. Akira S, Takeda K, Kaisho T (2001) Toll-like receptors: critical proteins linking innate and acquired immunity. Nat Immunol 2:675-680

36. Schultz C, Temming P, Bucsky P, Gopel W, Strunk T, Hartel C (2004) Immature anti-inflammatory response in neonates. Clin Exp Immunol 135:130-136

37. Rangel-Frausto MS, Pittet D, Costigan M, Hwang T, Davis CS, Wenzel RP (1995) The natural history of the systemic inflammatory response syndrome (SIRS). A prospective study. JAMA 273:117-123

38. Pinsky MR, Vincent JL, Deviere J, Alegre M, Kahn RJ, Dupont E (1993) Serum cytokine levels in human septic shock. Relation to multiple-system organ failure and mortality. Chest 103:565-575

39. Baumann H, Prowse KR, Marinkovic S, Won KA, Jahreis GP (1989) Stimulation of hepatic acute phase response by cytokines and glucocorticoids (discussion 295-286). Ann N Y Acad Sci 557:280-295

40. Tracey KJ, Lowry SF, Cerami A (1988) Cachetin/TNF-alpha in septic shock and septic adult respiratory distress syndrome. Am Rev Respir Dis 138:1377-1379

41. Tracey KJ, Fong Y, Hesse DG, Manogue KR, Lee AT, Kuo GC, Lowry SF, Cerami A (1987) Anti-cachectin/TNF monoclonal antibodies prevent septic shock during lethal bacteraemia. Nature 330:662-664

42. Hensler T, Hecker $H$, Heeg $K$, Heidecke CD, Bartels $H$, Barthlen W, Wagner H, Siewert JR, Holzmann B (1997) Distinct mechanisms of immunosuppression as a consequence of major surgery. Infect Immun 65:2283-2291

43. Ayala A, Chaudry IH (1996) Immune dysfunction in murine polymicrobial sepsis: mediators, macrophages, lymphocytes and apoptosis. Shock 6 Suppl 1:S27-S38

44. Majetschak M, Flach R, Kreuzfelder E, Jennissen V, Heukamp T, Neudeck F, Schmit-Neuerburg KP, Obertacke U, Schade FU (1999) The extent of traumatic damage determines a graded depression of the endotoxin responsiveness of peripheral blood mononuclear cells from patients with blunt injuries. Crit Care Med 27:313-318
45. Stout RD, Bottomly K (1989) Antigen-specific activation of effector macrophages by IFN-gamma producing (TH1) T cell clones. Failure of IL-4-producing (TH2) T cell clones to activate effector function in macrophages. J Immunol 142:760-765

46. Ulich TR, Yin S, Guo K, Yi ES, Remick D, del Castillo J (1991) Intratracheal injection of endotoxin and cytokines. II. Interleukin-6 and transforming growth factor beta inhibit acute inflammation. Am J Pathol 138:1097-1101

47. Schindler R, Mancilla J, Endres S, Ghorbani R, Clark SC, Dinarello CA (1990) Correlations and interactions in the production of interleukin-6 (IL-6), IL-1, and tumor necrosis factor (TNF) in human blood mononuclear cells: IL-6 suppresses IL-1 and TNF. Blood 75:40-47

48. Angele MK, Faist E (2002) Clinical review: immunodepression in the surgical patient and increased susceptibility to infection. Crit Care 6:298-305

49. Sheppard BC, Fraker DL, Norton JA (1989) Prevention and treatment of endotoxin and sepsis lethality with recombinant human tumor necrosis factor. Surgery 106:156-161

50. Ogle CK, Guo X, Chance WT, Ogle JD (1997) Induction of endotoxin tolerance in rat bone marrow cells by in vivo infusion of tumor necrosis factor. Crit Care Med 25:827-833

51. Cross AS, Sadoff JC, Kelly N, Bernton E, Gemski P (1989) Pretreatment with recombinant murine tumor necrosis factor alpha/cachectin and murine interleukin 1 alpha protects mice from lethal bacterial infection. J Exp Med 169:2021-2027

52. Medvedev AE, Lentschat A, Wahl LM, Golenbock DT, Vogel SN (2002) Dysregulation of LPS-induced Toll-like receptor 4 MyD88 complex formation and IL-1 receptor-associated kinase 1 activation in endotoxin-tolerant cells. J Immunol 169:5209-5216

53. Ferlito M, Romanenko OG, Ashton S, Squadrito F, Halushka PV, Cook JA (2001) Effect of cross-tolerance between endotoxin and TNF-alpha or IL-1beta on cellular signaling and mediator production. J Leukoc Biol 70:821-829

54. Ropert C.,Closel M.,Chaves A. C., Gazzinelli R. T. (2003) Inhibition of a p38/stress-activated protein kinase-2-dependent phosphatase restores function of IL-1 receptor-associate kinase-1 and reverses Toll-like receptor 2- and 4-dependent tolerance of macrophages. J Immunol 171:1456-1465 